\title{
Influences of Career Planning, Leadership and Organizational Culture towards Employee Work Effectiveness
}

\author{
Hafni Rizanuddin \\ Industrial Engineering, Universitas Majalengka, Indonesia \\ hafni.rn@unma.ac.id
}

\begin{abstract}
This study was conducted at the Regional Civil Service Agency of Majalengka Regency. The purpose of this research is to analyze the influence of career planning, organizational culture and the leadership simultaneously and partially to the effectiveness of employee work. The methods used in this research are descriptive and verification methods. The primary data collection was conducted using census techniques, i.e. the entire population was used as the subject of research. Data sources in this research are primary and secondary data, with data analysis techniques using path analysis. The results showed that career planning conducted by Regional Civil Service Agency of Majalengka Regency is wellperceived; the leadership of the Regional Civil Service Agency of Majalengka Regency is well perceived. That is, the leader of Regional Civil Service Agency of Majalengka Regency has been carrying out his tasks and functions fairly well, especially in order to improve the basic task of Regional Civil Service Agency in providing public services; the organizational culture that makes up the organizational values and norms is well-perceived; Employees at Regional Civil Service Agency of Majalengka Regency are assessed as effective in carrying out their daily work; Career planning is verification a positive and significant influence on the effectiveness of employee work; Leadership proved to have a positive and significant influence on employee work effectiveness; The organizational culture is empirically positive and significant influence on the effectiveness of work; Simultaneously between career planning, leadership and organizational culture affects positively and significantly to the effectiveness of the work.
\end{abstract}

Keywords

career planning, leadership; organizational culture and employment effectiveness officers Sumatera Province

\section{Introduction}

One of the most important resources in an operational activity of government and private agencies is human resources. Human resources is an important factor because it is an asset in the organization that can provide benefits other than energy, as well as creativity and passion that also realize the organization's performance. Because the organization in this case a manager can not work himself in achieving the desired goal, a manager needs labor, in this case, the employee. Organizations will be highly dependent on how employees can develop their skills in the field of managerial, human relations, and technical operations. Therefore, officers must obtain special attention from the leaders in carrying out the work given to him. If the work provided can be done well, then according to the wishes of the leader. But if the task given to the employee could not be carried out properly, then a manager should need to know what the cause is. Every government and private agency not only expects employees who are capable, capable, and skilled but most 
importantly they want to work hard and want to achieve optimal work results as effectively as possible.

The effectiveness of work is very important in an organization because it can increase the profitability of the company (Paul, 2018) and increase the value for public organizations (Garcia-Sanchez, Cuadrado-Ballesteros, \& Frias-Aceituno, 2013). With the creation of work effectiveness, employees will try to overcome and solve the problems faced in the performance of their duties and jobs. Conversely, ineffectiveness in work will be bad for the success of the organization, for example, employees will be easily discouraged when it gets difficulties in carrying out tasks so it is difficult to achieve a set goal. To achieve the effectiveness of work is influenced by several factors such as accuracy in career planning, leadership roles, and supporting organizational culture.

Cultural values can be used as a guideline for an organization is a trusted cultural value, believed by all members of the organization. The core value of organizational culture is usually more philosophically even somewhat similar to the marketing slogan and emphasizes the quality that is the character of an organization. The description of organizational culture will provide a clear benefit to human resources. The human resource is not confused, knowing the aspect he pleased, but there is an indirect oneness of the very important thing. These cultural values are further expressed by (Robbins, 2012) as a characteristic that can be used as a measure to give the organization a cultural picture. The seven characteristics are innovation and risk-taking, detailed attention, result orientation, people orientation, team orientation, aggression, and stability. The importance of culture in a working environment forms a behavior that supports organizational performance (AHMED \& Shafiq, 2014), so organizations must be able to carry and invite employees to make adjustments with existing organizational culture to be a grip in achieving employee performance. (Mangosteen, Yuesti, \& Sapta, 2018).

Every organization of both corporate organizations, social organizations, and government organizations has a goal that can be achieved through the implementation of certain work by using all the resources in the organization and the most instrumental in achieving the objectives of the organization is human resources. Regional Civil Service Agency is a government means that has a significant role in realizing bureaucracy reform. This relates to the formulation of technical policies on the planning, procurement, development, placement, promotion, payroll, welfare, discipline, and dismissal of employees. Given the importance of the duties and functions of the Civil Service Agency, it is necessary to set up a career planning for the employees in the Regional Civil Service Agency. Good career planning will impact on the stability of government agencies and efforts to achieve the objectives and objectives of the government agency itself.

One aspect of human resource development that is very important to note is career planning that will impact on the effectiveness of employees ' work. Likewise with the condition in the Regional Civil Service Agency of Majalengka Regency which is incessantly to reform the bureaucracy, so that the arrangement of career planning officers is part of the main objective of Regional Civil Service Agency of Majalengka Regency in building the increasingly qualified employees. As in the research (Navaid, 2015) that career planning is very likely to build qualified employees. While research (Adekola, 2011) proves that career planning has a relationship with future employee career development also, career planning to build individuals to adapt to changes later (Rbu, Popa, \& Pipaș, 2014).

Career planning and career management will benefit individuals and organizations. Through career development programs, government agencies will improve employee performance and productivity, reduce employee turnover, and increase promotion 
opportunities for employees. For the employees themselves, career planning can encourage their self-readiness to use the available career opportunities. Every government agency always expects its employees to work well and achieve their field by what the management of government agencies wants. Previous research shows that employee career planning has a role in enhancing the effectiveness of work and performance (Afifah, 2011), while the research results (Ernita Septiana, 2012) show the opposite that the development of employee performance will affect the career development of employees. The proof of the results of the research is a form of empirical findings that confirm that the employee's career planning is associated with the effectiveness and performance of employees. However, employee career planning is meaningless if there is no support from leadership. Leadership in the organization is crucial, this is because the leadership factor can have a meaningful influence on personnel performance (Wendy Lor and Zubair Hassan, 2017), as leaders who plan, inform, create and evaluate decisions that must be implemented in the organization.

Factors related to the attitude, style, and behavior of leaders is very influential in the employees he led even affected by the performance of an organization. Leaders can influence morality, job satisfaction, security, quality of work-life, and especially the level of achievement of an organization (Karyono \& Samad, 2020). Ability and skill in the briefing is an important factor in the effectiveness of an organization. When organizations can identify leadership-related qualities, the ability to select effective leaders will increase. And if the organization can identify the effective conduct and leadership techniques of the organization, the various attitudes and techniques will be learned. In a governmental organization, success or failure in the execution of tasks and governance, influenced by leadership, through leadership and supported by the adequate capacity of government organizations, the implementation of good Governance will be realized; otherwise, the weakness of leadership is one of the reasons for the collapse of bureaucratic performance in Indonesia (Istianto, 2009). Leadership can be said as a way from a leader in directing, encouraging, and organizing all the elements in the group or organization to achieve the desired organizational objectives, resulting in maximum employee performance. With increasing, employee performance means achieving the work of a person or employee in realizing the objectives of the Organization.

\section{Literature Review}

Career planning is a decision-making process for determining the steps that will take place in a career to achieve a predetermined goal. Individual-centered career planning focuses more on individual careers (Serbes \& Albay, 2018), these plans are performed by employees themselves by analyzing their objectives and skills. Such efforts may consider the situation, both internal and external of the organization, to develop a person's career. (Mathis, 2006) explained that leadership is one of the most important factors in an organization because most of the success and failure of an organization is determined by the leadership in the organization, so the leader has a very important role in the career development of officers (Jonah, Hamid, \& Yusuf, 2018). Leadership involves influencing the process of determining organizational objectives, motivating follower behavior to achieve goals, influencing to improve their group and culture. (Timple, 2000) defines leadership is the process of social influence in which managers seek voluntary participation from subordinates in the effort to achieve organizational objectives. With the leadership, a leader has also described the direction and objectives that will be achieved from an organization, so leadership can be said to be very influential for the big name of the organization. Organizational culture includes values and standards that direct organizational actors ' behavior and determine the direction 
of the organization as a whole. Organizational culture is a unique symbol and interaction for every organization. This includes the way of thinking, behaving, beliefs that are equally owned by the members of the unit (Marquis, 2010:177). The combination of a systematic and well-planned employee career, good leadership, and flexible organizational culture will create high effectiveness (Akkermans \& Brenninkmeijer, 2015; Gochhayat \& Suar, 2017; Mitra Madanchian, Norashikin Hussein, Fauziah Noordin, 2017).

The effectiveness rate can be measured by comparing between predefined plans or targets with the results achieved, then the effort or the outcome of the work that is said to be effective, but if the effort or outcome of the work done is not achieved according to what is planned, then it is said ineffective. Hari Lubis and Martani Huseini (1987:55) expressed effectiveness as a very important concept in the organization because of the measure of the success of the Organization in achieving its objectives. Thus, effective measurements are not simple considering the different objectives of each organization and the diversity of objectives of the Organization itself.

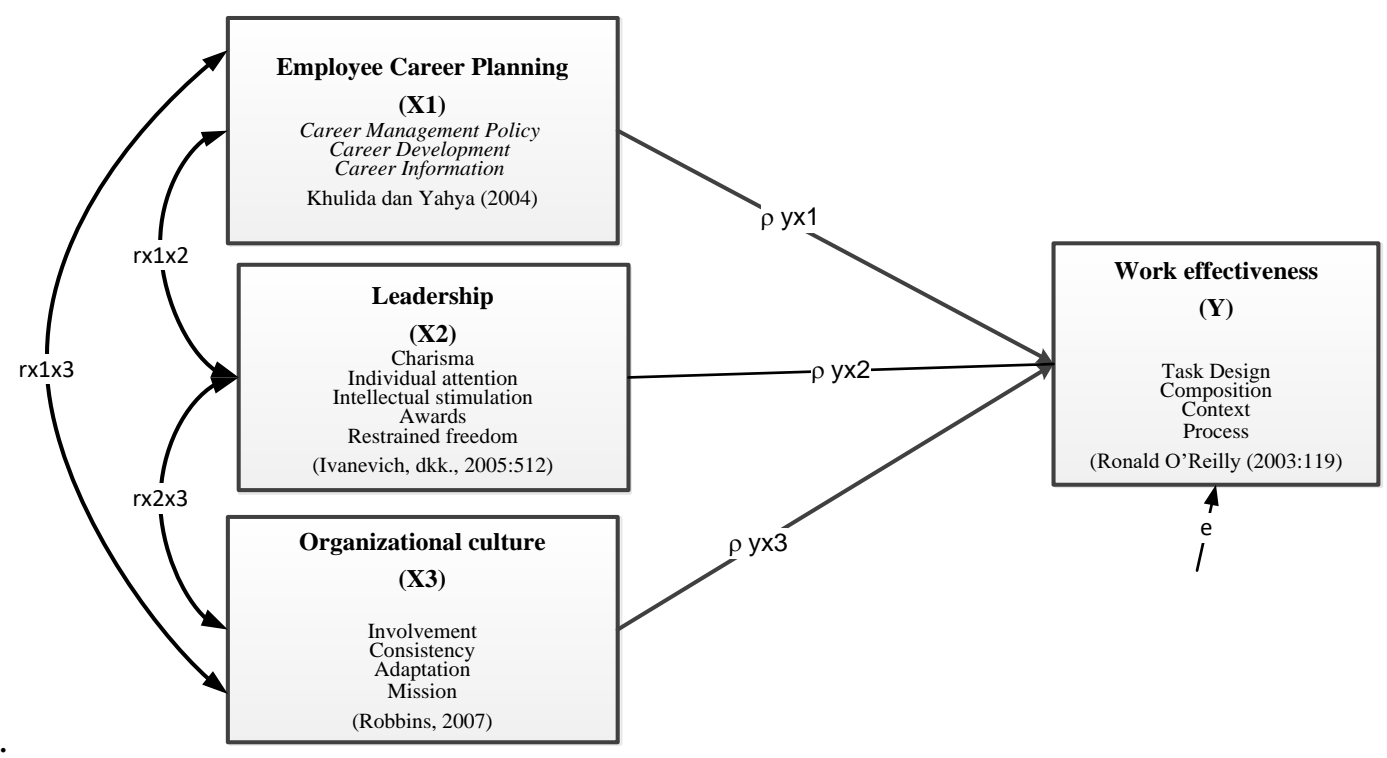

Figure 1. Research Paradigm

Based on the research paradigm figure then the research hypothesis is as follows:

1. There is a positive influence from career planning to the effectiveness of employee work

2. There is a positive influence from leadership to the effectiveness of employee work

3. There is a positive influence of organizational culture to the effectiveness of employee work

4. There is a positive influence from career planning, leadership and organizational culture simultaneously to the effectiveness of employee work.

\section{Research Method}

In this study, the object of the study was career planning of employees, leadership, organizational culture, and work effectiveness was measured using research questionnaires based on a likert scale of $1-5$, referring to the dimensions of the four variables resulting from the existing theory. Respondents in this study were officers and leaders of the Regional Civil Service Agency of Majalengka Regency while the subject of this research is the 
institutional Regional Civil Service Agency of Majalengka Regency. The subject of this study was intended to obtain immediate information on the factors that influence (employee career planning, leadership, and organizational culture) which was very dominant towards improving employee work effectiveness. Data analysis was done qualitatively or quantitatively to obtain clear inputs and descriptions regarding employee career planning, leadership, and organizational culture. In this study, the research population was as much as 44 people. The determination and sampling techniques refer to the opinion (Arikunto, 2008) which suggested if the population is less than 100, and then the population is taken all while sampling techniques used census techniques. The study was conducted in early February until the end of July 2019. Analysis of data carried out on the primary data of the field is divided into two types namely: the first part, the analysis of descriptive data in the form of diagram drawings were further discussed and confronted with concepts that have existed whether according to the theory, adding to the existing theories or contrary to existing theories. The second section, analysis of data with quantitative analysis, was with track analysis statistics, which was based on the type of data collected and its relevance to research objectives. Path analysis was a form of multi-regression analysis. This analysis was guided by a pathway diagram to help conceptualize problems or test complex hypotheses. In this way, it can be calculated the direct and indirect links of independent variables against dependent variables.

\section{Discussion}

The following will be outlined with a descriptive assessment recapitulation of career planning variables at the Regional Civil Service Agency of Majalengka Regency as follows:

Table 1. Research Variable Description

\begin{tabular}{|c|l|r|r|}
\hline No & \multicolumn{1}{|c|}{ Variable } & Average Score & Deviation Standard \\
\hline 1 & Career planning & 3.116 & 0.738 \\
\hline 2 & Leadership & 3.261 & 0.919 \\
\hline 3 & Organizational Culture & 2.884 & 0.798 \\
\hline 4 & Work Effectiveness & 3.379 & 0.949 \\
\hline
\end{tabular}

Source: Research Data analysis results

According to the table above, it was known that the average score of career planning variables was 3.116 with a standard deviation score of 0.738 . The results described that career planning was in a quite good category. The average score of a leadership variable was 3.261 with a standard deviation score of 0.919. The results described that the leadership was in a quite good category. The average score of a organizational culture variable was 2.884 with a standard deviation score of 0.798 . The results described that the organizational culture was quite good category. The average score of a leadership variable was 3.379 with a standard deviation score of 0.949 . The results described that the working effectiveness was in the category quite well. The verification analysis used in this study used path analysis aimed at analyzing the relationship causally between variables independent of the dependent variable. The first step in the path analysis was to correlate between independent variables. Correlation analysis aimed to measure the strength of a linear association (relation) between two variables as well as declare the degree of relation between the associated variables. In order to know the degree of relationship used the Bivariate correlation analysis model used to look for the degree of relationship, and the direction of the relationship, the higher the correlation score the closer related the three relationship of the variable. Based on the 
research data obtained can be counted on the contribution of direct or indirect influence as shown in Figure 1 below.

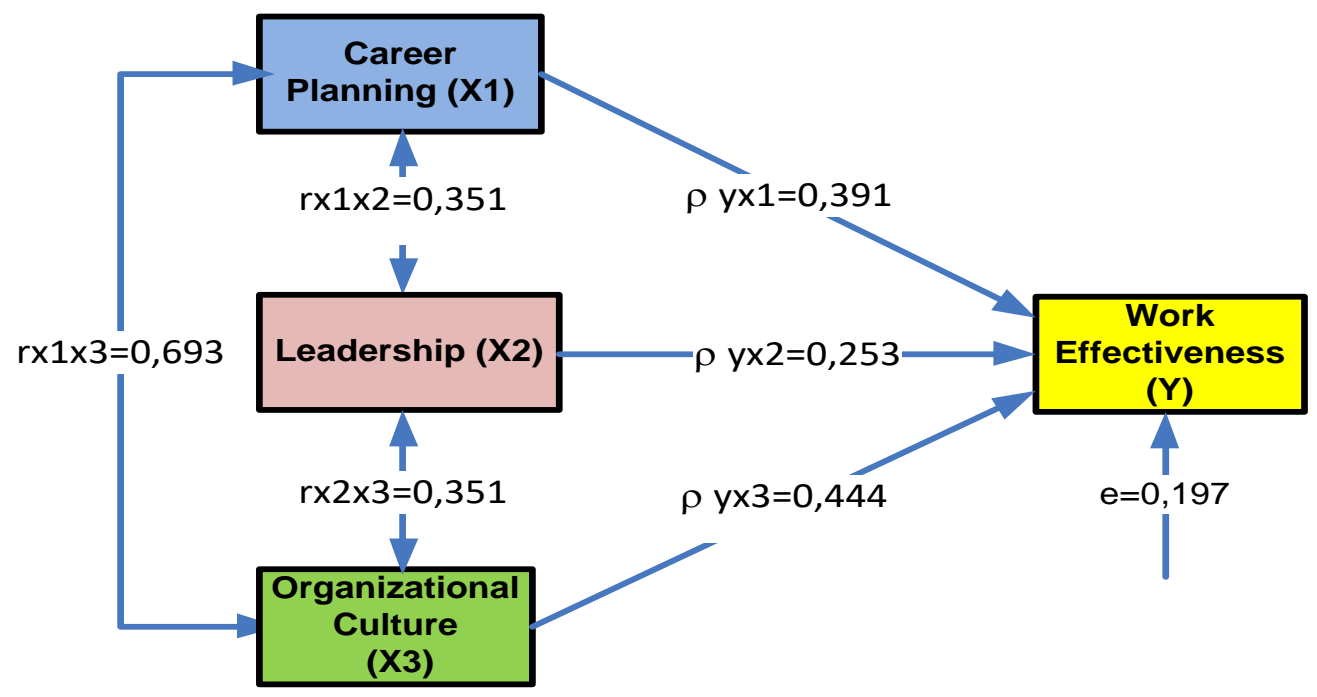

Figure 2. Structural Model of Path Way Coefficient

Direct influence of career planning on the effectiveness of work was $\left(0,391^{2} \times 100 \%\right)=$ $15,288 \%$. Indirect influence of career planning towards the effectiveness of work through leadership amounted to $(0,391 \times 0,351 \times 0,253 \times 100 \%)=3,472 \%$. Indirect influence of career planning towards the effectiveness of work through organizational culture amounted to $(0,391 \times 0,693 \times 0,444 \times 100 \%)=12,030 \%$. Total influence either directly or indirectly from career planning to the effectiveness of work of $(15,288 \%+3,472 \%+12,030 \%)=30,79 \%$. Based on the results of the hypothesis testing can be seen the t-count score of 3.968 with a significant score (P-value) greater than 0.05. Because t-count (3.968) was greater than t-table (1.960) then at a rate of error 5\% there was a strong reason to reject (Ho) and accept the research hypothesis $\left(\mathrm{H}_{1}\right)$, so that with a level of confidence $95 \%$ can be concluded that career planning has significant effect on the effectiveness of work. The results of this study supported with the results of research (Iin Angelia Taghulihi, 2015; Trivellas, Kakkos, Blanas, \& Santouridis, 2015) which proved empirically that career planning has a positive effect on effective performance. Direct influence of leadership against the effectiveness of work $\left(0,253^{2} \times 100 \%\right)=6,401 \%$. Indirect influence of leadership towards the effectiveness of work through career planning amounted to $(0.253 \times 0.351 \times 0.391 \times 100 \%)=3.472 \%$. Indirect influence of leadership towards the effectiveness of work through organizational culture amounted to $(0.253 \times 0.351 \times 0.444 \times 100 \%)=3.942 \%$. Total influence either directly or indirectly from leadership to the effectiveness of work amounting to $(6.401 \%+3.472 \%+$ $3.942 \%)=13.815 \%$. Based on the results of the hypothesis testing can be seen the $\mathrm{t}$-count score of 3, 333 with a significant score (P-value) greater than 0.05 . Because t-count (3.333) was greater than t-table (1.960) then at a rate of error 5\% there was a strong reason to rejected (Ho) and accepted the research hypothesis $\left(\mathrm{H}_{1}\right)$, so that with a level of confidence $95 \%$ can be concluded that the leadership has a significant effect on the effectiveness of work. The results of this study supported the results of research conducted by (Asrar-ul-Haq \& Kuchinke, 2016) that effective leadership can improve employee attitudes more effectively in establishing good performance. Direct influence of organizational culture to the effectiveness of work by $\left(0,444^{2} \times 100 \%\right)=19,714 \%$. Indirect influence of organizational culture to the effectiveness of work through career planning amounted to $(0,444 \times 0,351 \times 0,253 \times 100 \%)=$ 
$3,942 \%$. Total influence either directly or indirectly from the organizational culture to the effectiveness of work of $(19.714 \%+12.030 \%+3.942 \%)=35.686 \%$. Based on the results of the hypothesis testing can be seen the T-count score of 4.510 with a significant score (Pvalue) greater than 0.05 . Because $\mathrm{T}$-count (4.510) is greater than T-table (1.960) then at a rate of error 5\% there was a strong reason to reject (Ho) and accept the research hypothesis $\left(\mathrm{H}_{1}\right)$, so that with a level of confidence $95 \%$ can be concluded that the organizational culture has significant effect on the effectiveness of work. The results of this study supported the results of research conducted by (ABU-Jarad, 2010; Shahzad, 2012) that proved that organizational culture has a significant effect on effective performance enhancement that impacts organizational performance.

Total simultaneous influence given by career planning, leadership and organizational culture to the effectiveness of work by $(30,79 \%+13,815 \%+35,686 \%)=80.291 \%$ and the remaining $19.709 \%$ were influenced by other variables outside of the study. Based on the results of the hypothesis testing can be seen the F-count score of 54.411 with a significant score (P-value) greater than 0.05. Because F-count (54.411) was greater than the F-table (2.750) then at a rate of error 5\% there was a strong reason to reject (Ho) and accept the research hypothesis $\left(\mathrm{H}_{1}\right)$, so that with a level of confidence $95 \%$ can be concluded that career planning, leadership and organizational culture are significantly simultaneously on the effectiveness of work.

\section{Conclusion}

The career planning conducted by the Regional Civil Service Agency of Majalengka Regency is well perceived. This means that the career planning system in the Regional Civil Service Agency of Majalengka Regency already has a fairly good system. But if it is seen from the categorization, the results of the research on career planning in a descriptive still not optimal, because still being on the third level, good enough, so that it can not be concluded well and very good. To achieve good and very good, needed to be aware of the current career planning system. The leadership of the Regional Civil Service Agency of Majalengka Regency is well perceived. That is, the leadership of the Regional Civil Service Agency has been carrying out his tasks and functions quite well, especially to improve the basic task of the Regional Civil Service Agency in providing public services. The results of the leadership obtained at the third level are good enough, so there are still two more levels that are good and very good that need to be done by the principal task of current and future leadership. The organizational culture that makes up the organizational values and norms is well perceived.

This indicates that the current cultural conditions show sufficient support for employee work, even if they have not yet reached the optimal point. Employees at the Regional Civil Service Agency of Majalengka Regency are assessed as effective in carrying out their daily work. This indicates that employees have sufficient ability to work, even if they have not reached the optimal point. Career planning is empirically has a positive and significant influence on the effectiveness of employee work. That is, effectively and whether an employee in carrying out his work depends on the transparency of the employee career assessment system. Leadership proved to have a positive and significant influence on employee work effectiveness. These results indicate that the role of the leader in an organization is vital, in addition to implementing the vision and mission of the Organization as a motivator to his subordinates to work optimally. The organizational culture is empirically positive and significant to influence the effectiveness of the work. These results indicate that organizational culture is a decisive factor in the harmonization of work. Simultaneously between career planning, leadership, and organizational culture affect positively and 
significantly to the effectiveness of the work. These results indicate that the increasing number of factors supporting the effectiveness of work (career planning, leadership, and organizational culture) can have a stronger influence when compared to a partial.

\section{References}

Abu-jarad, I. Y. (2010). A Review Paper on Organizational Culture and Organizational Performance. International Journal of Business and Social Science, 1(3), 26-46.

Adekola, B. (2011). Career Planning and Career Management as Correlates For Career Development and Job Satisfaction a Case Study of Nigerian Bank Employees. Australian Journal of Business and Management Research, 1(2), 100-112.

Afifah, M. (2011). Pengaruh Motivasi, Kompensasi dan Pengembangan Karir terhadap Kinerja Guru SMK Nusantara. Jurnal Jurusan Manajemen Fakultas Ekonomi Dan Bisnis Universitas Islam Negeri Syarif Hidayatullah.

Ahmed, M., \& Shafiq, S. (2014). The Impact of Organizational Culture on Organizational Performance: Global Journal of Management and Business Research: A Administration and Management, 14(3).

Akkermans, J. O. S., \& Brenninkmeijer, V. (2015). It's All About Careerskills: Effectiveness of a Career Development Intervention For Young Employees. Human Resource Management, 54(4), 533-551. https://doi.org/10.1002/hrm

Arif, S., Zainudin, Hamid K. A. 2019. Influence of Leadership, Organizational Culture, Work Motivation, and Job Satisfaction of Performance Principles of Senior High School in Medan City. Budapest International Research and Critics Institute-Journal (BIRCIJournal) (2): 239-254.

Arikunto, S. (2008). Prosedur Penelitian Suatu Pendekatan Praktik. Jakarta: Rineka Cipta.

Asrar-ul-haq, M., \& Kuchinke, K. P. (2016). Impact of leadership styles on employees attitude towards their leader and performance : Empirical evidence from Pakistani banks. Future Business Journal, 2(1), 54-64. https://doi.org/10.1016/j.fbj.2016.05.002

Dailami, Kholil, S. and Lubis, L. 2020. The Communication Patterns of Leadership in Improving Work Ethic of Lecturer and Staff in Asahan University (Islamic Communication Perspective). Budapest International Research and Critics InstituteJournal (BIRCI-Journal) (3): 469-476.

Ernita Septiana. (2012). Pengaruh Kesiapan Pegawai Menuju Remunerasi Terhadap Kinerja Pegawai. Jurnal Ekonomi Manajemen Sumber Daya Manusia, 12(2).

Garcia-sanchez, I. M., Cuadrado-ballesteros, B., \& Frias-aceituno, J. (2013). Determinants of Government Effectiveness. International Journal OfPublic Administration, (July). https://doi.org/10.1080/01900692.2013.772630

Gochhayat, J., \& Suar, D. (2017). Influence of Organizational Culture on Organizational Effectiveness: The Mediating Role of Organizational Communication Influence of Organizational Culture on Organizational Effectiveness: The Mediating Role of Organizational Communication. Global Business Review, 18(3), 691-702. https://doi.org/10.1177/0972150917692185

Iin Angelia Taghulihi. (2015). The Effect of Motivation, Career Development, and Work Discipline on Employee Performance at PT. Bank Sulutgo in Tagulandang. Jurnal Berkala Ilmiah Efisiensi, 15(05), 925-930.

Istianto, B. (2009). Manajemen Pemerintahan Dalam Persepektif. Pelayanan Publik. Jakarta: Mitra Wacana Media.

Karyono, O., \& Samad, M. Y. A. (2020). The Effect of Strategic Leadership and Motivation Towards Satisfaction and its Impact on Employee Performance. International Journal of 
Advanced Science and Technology, 29(5), 6120-6124.

Kuswati, Y. 2019. Motivation Role in Improving Work Effectiveness. Budapest International Research and Critics Institute-Journal (BIRCI-Journal) (2): 281-288.

Manggis, I. W., Yuesti, A., \& Sapta, I. K. S. (2018). The Effect of Career Development and Organizational Culture to Employee Performance with Motivation of Work as Intervening Variable in Cooperation in Denpasar Village. International Journal of Contemporary Research and Review, 9(7), 20901-20916.

Mathis, R. L. \& J. H. J. (2006). Human Resource Management: Manajemen Sumber Daya Manusia (Dian Angelia, ed.). Jakarta: Salemba Empat.

Mitra Madanchian, Norashikin Hussein, Fauziah Noordin, H. T. (2017). Leadership Effectiveness Measurement and Its Effect on Organization Outcomes. Procedia Engineering, 181, 1043-1048. https://doi.org/10.1016/j.proeng.2017.02.505

Mizaj. 2018. Dayah Darussalam Network and Dayah Awakening in Aceh. Budapest International Research and Critics Institute-Journal (BIRCI-Journal) (1):: 13-22.

Navaid, N. (2015). Impact of Individual Career Planning On Employee Career Development : A Study of Banking Sector of Karachi . 1- INTRODUCTION. International Journal of Management Sciences and Business Research, 4(10), 99-114.

Paul, S. R. U. and G. D. (2018). The Impact of Effective Work Design in Achieving Profitability in Organization The Impact of Effective Work Design in Achieving Profitability in Organization ( A Case Study of Selected Companies in Nigeria ). International Journal of Humanities Social Sciences and Education, 2(1), 144-152.

Rbu, J. S. Î, Popa, M., \& Pipaș, M. D. (2014). Professional Career Planning - Practice and Results. International Journal of Academic Research in Business and Social Sciences, 4(7), 350-362. https://doi.org/10.6007/IJARBSS/v4-i7/1014

Robbins, P. S. dan T. A. J. (2012). Perilaku Organisasi. Jakarta: Salemba Empat.

Serbes, M., \& Albay, M. (2018). Importance of Career Planning and Development in Education. International Journal of Social Sciences \& Educational Studies, 4(2), 149154. https://doi.org/10.23918/ijsses.v4i2sip149

Shahzad, F. (2012). Impact of Organizational Culture on Organizational Performance : An Overview. Interdisciplinary Journal of Contemporary Research in Business, 975-985.

Timple, A. D. (2000). Seri Manajemen Sumber Daya Manusia Kepemimpinan. Jakarta: Elex Media Komputindo.

Trivellas, P., Kakkos, N., Blanas, N., \& Santouridis, I. (2015). The impact of career satisfaction on job performance in accounting firms . The mediating effect of general competencies. Procedia Economics and Finance, 33(15), 468-476. https://doi.org/10.1016/S2212-5671(15)01730-X

Wendy Lor and Zubair Hassan. (2017). The Influence of Leadership on Employee Perfromance among Jewellery Artisans in Malaysia. International Journal of Accounting \& Business Management, 5(1), 14-33.

Yunus, N. M., Hamid, N., \& Yusuf, R. M. (2018). Leadership and Career Development on Organizational Commitment and Its Impact on the Performance of Employees of PT. Bank Mandiri (Persero) Tbk Area Makassar Kartini. Hasanuddin Journal of Applied Business and Entrepreneurship, 1(2), 50-60. 